\title{
Analysis of Ways to Strengthen the Management of Marine Fishery Resources in China in the New Period
}

\author{
Zhi Chen, Yan Liu, Chaojie Yang*, Xiaoxuan Xing, Qianqian Wang, Lican Su \\ Hainan Tropical Ocean University, Sanya 572022, Hainan, China. \\ E-mail: yangchaojie1986@163.com
}

Project: Supported by Scientific Research Foundation of Hainan Tropical Ocean University(Project number: RHDRC201907); Hainan University Education and Teaching Reform Research Project(Project number: Hnjg2020-89)

Abstract: This article mainly starts with the concept and basic characteristics of China's marine fishery resources. On this basis, it analyzes the utilization status of China's marine fishery resources and the problems existing in the management of marine fishery resources for discussion, and finally proposes effective ways to strengthen the management of marine fishery resources, aiming at providing help for the sustainable development of China's marine fishery resources.

Keywords: Marine Fishery; Resource Management; Effective Measures

China has a vast coastline and abundant marine fishery resources. In the past, under the extensive economic development model, marine fishery resources provided important resource support for China's national economic development and social stability. Some coastal cities accumulated economic wealth through the development of fishery resources. However, with the increase of the population, the unreasonable application methods in the development and utilization of traditional marine fishery resources have caused irreversible harm to marine fishery resources. In this new era of the implementation of the concept of sustainable development, it has become a top priority to change the marine fishery resource management in China and build a new model of refined marine fishery management.

\section{Current status and problems of China's marine fishery resources management in the new era}

First, there is asymmetric information in the management of marine fishery resources in China. In all sea areas of China, problems such as oversized fishing fleets and excess fishing power are common. With the development of science and technology, the scale of marine fishing vessels and fishing output has shown an exponential increase in recent years. Although the relevant government departments have carried out scientific management and calculation of the output of marine fishery resources, it has not been implemented on every fishing vessel in every sea area. As a result, although the superiors have issued fishery fishing product standards, in the development of fishery economy, the subordinates cannot dynamically update the standard parameters in real time, so the standard function is not high.

Second, the main body of China's marine fishery resource management has been lost. The process of utilization and development of marine fishery resources has a spontaneous characteristic, that is, fishermen are an important subject of marine fishery resource management. However, at present, the relevant state departments are not very well regulated regarding fishermen's fishing behavior. Therefore, driven by interests, the current fishing practitioners blindly care about their immediate interests and carry out predatory production, which seriously leads to the depletion of offshore fishery resources.

Copyright (C) 2020 Zhi Chen et al

doi: $10.18282 /$ le.v9i6.1326

This is an open-access article distributed under the terms of the Creative Commons Attribution Non-Commercial License

(http://creativecommons.org/licenses/by-nc/4.0/), which permits unrestricted non-commercial use, distribution, and reproduction in any medium, provided the original work is properly cited. 
Third, there is an unreasonable system in the management of marine fishery resources in China. The Fishery Law is an important legal basis for the management of marine fishery resources in China. However, in the provisions of the Fishery Law, marine fishery resources are required to adopt the principle of "unified leadership and hierarchical management". In theory, this management principle realizes unified management and adjusts measures to local conditions and time. However, in specific management activities, hierarchical management is the main body, and unified leadership is not strong. As a result, although the Ministry of Agriculture proposed relevant indicators for marine fisheries fishing, the specific implementation effect was not good.

Fourth, China's laws and regulations for the management of marine fishery resources have not yet been perfected. In recent years, although the country has done a lot of work on marine fishery legislation, it has focused on the formulation of management laws, such as penalizing and managing violations of fishery laws, but it lacks a systematic approach to fishery behavior and the construction of management mechanism. For example, so far, there are still unclear subjects and insufficient supervision and management for the trading and registration management of fishing boats.

\section{The optimization approach of China's marine fishery resources management in the new era}

\subsection{It is required to give full play to the role of each subject and do a good job in the overall management of marine fishery resources}

First, it is required to carry out publicity and education for fishermen and fishery-related enterprises to enhance their active and subjective role in the management of marine fishery resources. The main body of traditional marine fishery resource management is mainly related to government departments, which leads to problems such as low enforcement and asymmetric information in marine fishery resource management. At present, if the whole society attaches great importance to the management of marine fishery resources, starting with every fisherman and every marine fishery enterprise, it can lay a good foundation for the integrity of marine fishery resources. This requires publicity and education to strengthen the construction of awareness. The education and management of fishermen in various sea areas can be carried out through regular publicity and cultivation meetings.

Second, give full play to the coordination role of relevant government departments to ensure that the scientific management of marine fishery resources is carried out in an orderly manner. When fishermen and fishery companies have the awareness of scientific management of marine fishery resources, it is necessary for relevant government departments to play the role of overall planning, based on the overall management of marine resources, and allocate management measures to each fisherman. For example, in the development of scientific control of fishery catch production, it is necessary to limit the maximum catch volume of fishermen in each sea area. At the same time, it is necessary to stipulate the fishing method adopted by the fisherman and the size of the fish caught, and ensure the information sharing, to implement scientific management measures for marine fishery resources.

\subsection{It is required to establish and improve relevant legal systems, and do a good job in the institutionalized and professional management of marine fishery resources}

First, improve China's relevant systems for the management of marine fishery resources. In view of the shortcomings of the current marine fishery resource management system, it is required to adopt the right countermeasures to achieve the optimization and perfection of the superstructure. For example, incorporate the management of marine fishery resources into the work report of the local government, realize the unification of powers and responsibilities for the management of marine fishery resources, and develop a detailed management system. Only in this way can it be ensured that every element of marine fishery resources be managed as a whole. The situations where the superiors and subordinates are evasive about management responsibilities should be avoided.

Second, strengthen the supervision, implementation and management of China's marine fishery resources management system. At present, China has established a number of marine fishery resource management systems, such as a fishing moratorium system, a fishing license system, and a collection system for value-added protection fees. However, in fact, the degree of implementation and application efficiency of these systems are not obvious. This is mainly because 
the illegal costs of related management systems are too low, and the enforcement of some systems is not strong. For example, for the fishing moratorium system, it is required to implement the relevant prohibition of fishing in accordance with the law of reproduction, growth, and development of fishery resources. But in fact, due to the wide range of marine fishing areas, some fishermen still illegally enter the closed fishing areas to fish. At the same time, some fishermen will start retaliatory fishing before or after the fishing moratorium. Therefore, it is required to strengthen the law enforcement and management of usual fishery behaviors, strengthen the supervision and management of these illegal behaviors by improving diversified laws and regulations, and actively promote the diversified development of the ownership of marine fishery resources in the new process, which can fundamentally improve the enthusiasm and initiative of fishermen in protecting marine fishery resources.

\subsection{Improve the technical means of marine fishery resource management}

First, introduce information technology to carry out dynamic monitoring and management of marine fishery resources. There is an important problem in the management of marine fishery resources in China, and it is impossible to carry out the dynamic management of marine fishery resources. For example, a comprehensive understanding of the total amount of marine fishery resources will help formulate more specific and effective management policies. With the development of information technology, it is currently required to be able to introduce some information technology, Internet technology, etc., to carry out effective supervision and management of marine fishery resources. For example, in the coastal waters of China, a marine fishery resource management system is established to monitor and manage data and geographic location of various elements of marine fishery resources, and corresponding management measures should be taken to effectively avoid illegal fishing behaviors.

Second, research and develop innovative, green, and sustainable marine fishing equipment technology. With the development of social science and technology, more and more large-scale fishing boats have entered the fishery economy, which lays down hidden dangers for overfishing. At the same time, there are some extensive fishing tools and fishing technologies that still occupy the current fishing industry. This requires technical management of the fishing market. By eliminating the outdated, extensive and unscientific tools from the market, and adopting green and sustainable fishing equipment and technical methods, it is possible to create a good fishing industry atmosphere and realize the effective management of marine fishery resources.

\section{Conclusion}

In summary, in the new era, there are obvious deficiencies and loopholes in the management of marine fishery resources in China, which seriously affect the sustainable development of marine fishery resources. This requires to prescribe the right remedy for the case, and through the promotion and education of the importance of marine fishery resource management in the whole society, ensure that the government and social entities are actively involved in the management of marine fishery resources. The second is to be able to give full play to the government's macro-control role, do a good job in the construction of relevant policies, institutional mechanisms, and effectively regulate the management of marine fishery resources. Finally, it is required to start with scientific and technological means, strengthen the professional level of marine fishery resource management, and adopt modern and refined concepts and management systems.

\section{References}

1. Chen D. Research on the talent team construction of marine industry enterprises in Fujian province. Fujian Agriculture and Forestry University 2018.

2. Liu L, Gao W. Analysis of the ways and countermeasures for Zhanjiang's marine industry to connect with the "Belt and Road". Modern Agricultural Science and Technology 2018; 15: 265-267.

3. Liu W. Research on the status and improvement of marine environmental protection in the new era. Environment and Development 2018; 3008: 218-219. 